UDC 378.147

DOI https://doi.org/10.24919/2308-4863/38-3-24

\author{
Yuliia SAMOILOVA, \\ orcid.org/0000-0001-9578-0350 \\ Candidate of Pedagogic Sciences, \\ Associate Professor at the Department of Humanities \\ Sumy Branch \\ of Kharkiv National University of Internal Affairs \\ (Sumy, Ukraine) samoylova_yulya@ukr.net
}

Tetiana SERHIIENKO, orcid.org/0000-0001-5680-994X

Candidate of Pedagogic Sciences,

Associate Professor at the Department of Foreign Languages and Military Translation

Hetman Petro Sahaidachny National Army Academy

(Lviv, Ukraine) tanyasergh@gmail.com

\title{
METHODS OF SOFT SKILLS DEVELOPMENT IN THE PROCESS OF LEARNING FOREIGN LANGUAGES BY FUTURE LAW-ENFORCEMENT AND MILITARY OFFICERS
}

It is noted in the article that modern post-industrial society requires a new approach to education and new knowledge and skills from modern professionals. The modern labor market requires specialists who do not have just professional knowledge (so-called "hard skills"), but also "flexible" skills (or soft skills). Particularly soft skills, which include teamwork, analytical skills, flexibility and adaptability, determination, the ability to express their ideas and transform others, knowledge of foreign languages, help to demonstrate and use professional skills at the highest level.

For the future law-enforcement and military officers, who are currently subject to high professional requirements, including the need to speak a high level of a foreign language, the development of such skills is extremely important. It is necessary to reorient education to the development of soft skills of students and cadets. Mastering a foreign language communicative competence is one of the effective tools for developing soft skills.

Despite the fact that recently more and more attention is paid to the study of the role and place of soft skills in the education system, this problem still remains insufficiently studied in Ukrainian educational practice. It is necessary to pay attention to the methods of teaching a foreign language, which will promote the development of students' and cadets'soft skills. This article is aimed at studying this issue.

The article substantiates the requirements for foreign language training of modern law-enforcement and military officers. It is noted that the need to communicate in foreign languages, caused by the demands of the labor market, necessitates the possession of social and communication skills. Communicative approach is the main in the process of foreign languages study, and the widespread use of innovative learning technologies based on problem-situational learning practices, building an active learning environment, aimed at developing cases, role-playing games, independent scientific creativity, but not just reproduction of already available information, promotes the formation of soft skills. The teaching methods analyzed in the article promote the development of independent problem-based thinking in students and cadets, as well as skills to operate with information, and not just focus on the language form. To achieve effective results in learning a foreign language, it is necessary to implement the educational process through both traditional and innovative teaching methods in their harmonious combination.

Key words: soft skills, foreign language communicative competence, professional training, teaching methods, interactive technologies.

Юлія САМОЙЛОВА,

orcid.org/0000-0001-9578-0350

кандидат педагогічних наук,

доиент кафедри гуманітарних дисииплін

Сумської філії

Харківського національного університету внутрішніх справ

(Суми, Украӥна) samoylova_yulya@ukr.net

Тетяна СЕРГІЕНКО,

orcid.org/0000-0001-5680-994X

кандидат педагогічних наук,

доцент кафедри іноземних мов та військового перекладу Національної академії сухопутних військ імені гетьмана Петра Сагайдачного (Львів, Україна) tanyasergh@gmail.com 


\section{МЕТОДИ РОЗВИТКУ SОFТ SКILLS У ПРОЦЕСІ ВИВЧЕННЯ ІНОЗЕМНИХ МОВ МАЙБУТНІМИ ПРАВООХОРОНЦЯМИ ТА ВІЙСЬКОВОСЛУЖБОВЦЯМИ}

У статті зазначено, щз сучасне постіндустріальне суспільство вимагає нового підходу до освіти та нових знань, умінь та навичок від сучасних фахівиів. Сучасний ринок праці вимагає спеціалістів, які володіють не лише професійними знаннями (так званими “hard skills"), а і «гнучкими» навичками (soft skills). Caме soft skills, до яких входить командна робота, аналітичні здібності, гнучкість та адаптованість, рімучість, здатність пояснити свої ідеї та переконувати інших, навички публічних виступів, володіння іноземними мовами тощо, допомагають продемонструвати та використати професійні навички на найвищому рівні.

Для майбутніх прачівників правоохоронних органів та військовослужбовців, до яких зараз ставляться високі професійні вимоги, зокрема і вимога володіти на високому рівні іноземною мовою, розвиток таких навичок є надзвичайно актуальним. Необхідна переорієнтація освіти на розвиток у студентів та курсантів caме "soft skills". Оволодіння іншомовною комунікативною компетенцією є одним із ефекттивних інструментів розвитку "soft skills".

Не дивлячись на те, що останнім часом все більше уваги приділясться дослідженню та вивченню ролі і місия гнучких навичок у системі освіти, ия проблема залишається ще не достатньо вивченою у вітчизняній освітній практиці. Необхідно акцентувати увагу саме на методах навчання іноземній мові, які сприятимуть розвитку гнучких навичок у студентів та курсантів. Саме на вивчення ичього питання націлена ия стаття.

У статті обтрунтовано вимоги, які висуваються до іншомовної підготовки сучасних прачівників правоохоронних органів та військовослужбовиів. Зазначено, щчо потреба у спілкуванні іноземними мовами, спричинена вимогою ринку праиі, зумовлює необхідність володіння сочіальними та комунікативними навичками. Комунікативний підхід є основним у вивченні іноземних мов, а широке застосування інноваційних технологій навчання, які трунтуються на проблемно-ситуачійних практиках навчання, побудові активного навчально-пізнавального середовища, спрямовані на розроблення кейсів, рольових ігор, на самостійну наукову творчість, а не на репродуктивне відтворення вже наявної інформаціï, щчо сприяє формуванню “soft skills”. Проаналізовані в статті методи навчання сприяють розвитку самостійного проблемного мислення у здобувачів вищзӧ освіти, а також навичок уміло оперувати інформацією, а не лише орієнтацією на мовну форму. Для досягнення ефективних результатів у вивченні іноземної мови необхідно реалізовувати освітній процес як через традиційні, так $і$ через інноваційні методи навчання в їх гармонійному комбінуванні.

Ключові слова: soft skills, іншомовна комунікативна компетентність, професійна підготовка, методи навчання, інтерактивні технологї.

Problem statement. With the transition to a post-industrial society, i.e. a society of theoretical knowledge, science, innovation, new intellectual technologies, there is a significant change in the requirements for knowledge, skills and abilities acquired in higher education. After the signing of the Bologna Declaration, new programs and initiatives emerged that aimed to find a pan-European consensus in determining what university graduates should be able to do after graduation. The state of readiness for modern effective professional activity of a university graduate is determined not only by the presence of a certain system of professional knowledge, skills and abilities (hard skills) that help him perform the functions assigned to him by the state and society.

Special skills, called "flexible" or "sof", are needed. Particularly these "soft skills" help to demonstrate and use professional skills at the highest level. These skills include the ability of the specialists to communicate, work in a team, persuade, solve problems, make decisions, manage their time, motivate themselves and others. Moreover, recently more and more researchers are talking about shifting the emphasis from "hard skills" to "soft skills" of employees. That is, one of the factors of success in future professional activity may be the reorientation of education to the development of students' "soft skills". The field of educational training of future lawenforcement and military officers is no exception.
Moreover, among the main competencies of soft skills, both the Council of Europe and the European Commission have identified foreign and intercultural competencies that allow a qualified specialist to carry out effective interpersonal communication in their field.

Analysis of researches. The Ukrainian scientists E. Eingorn, N. Oleksiv, N. Dluhunovych, O. Kazachiner, K. Koval, Y. Lavrysh, foreign researchers L. Taylor- Stone, R. Tewari and others have studied the notion of soft skills and the aspects of their development in the context of professional training. However, it should be noted that the concept of "soft skills", as well as pedagogical conditions for their development in students and cadets, are relatively new and still insufficiently studied in modern domestic pedagogical thought.

The purpose of the article is to determine the pedagogical conditions and methods of soft skills forming of future law-enforcement and military officers in the process of learning foreign languages.

Presentation of the basic material. Proficiency in English is recognized as a basic life skill of the XXI century, so learning foreign language communicative competence in higher education is seen as a direct means of fulfilling the social order of the labor market for qualified personnel, namely the formation of soft skills based on professional skills.

Even more than 10 years ago, data were published that graduates of powerful world universities lack 
communication skills, the so-called soft skills (Boone, 2009), which include effective cooperation in a team, argumentation of one's own opinion, establishment of communication channels in the company etc. Cambridge Dictionary defines the term "soft skills" as a set of communication skills that allow you to communicate effectively and work in a team. This fact is confirmed by the studies conducted by Harvard University, the Carnegie Endowment for International Peace and the Stanford Research Institute, which found that success in the professional field depends by $75-85 \%$ on the level of formation of "soft skills" and only by $15-25 \%$ of "hard skills" (Watts, 2008).

At the current stage of reforming the Armed Forces of Ukraine and transition to NATO standards, there is an urgent need to strengthen the language training of military specialists based on international standards, namely foreign language proficiency at SMR-2 level, sufficient for foreign language communication in everyday and office situations. Knowledge of foreign languages by personnel in the Ministry of Defense of Ukraine is an important factor in reforming and developing the Armed Forces of Ukraine, implementing Euro-Atlantic standards and achieving interoperability with the armed forces of NATO member and partner countries, participating in multinational operations, training and more (Osnovni zasady, 2019: 1). Speaking of the National Police of Ukraine, it should be noted that high-quality training of future law enforcement officers is impossible without the use of positive international experience, and further successful operation of police is impossible without cooperation with police in leading countries, which is possible only with foreign languages. The disciplines "Foreign language", "Foreign language for professional purposes" are included in the block of compulsory educational components of training of future law-enforcement and military officers, which testifies to the important place of foreign language in training specialists of these profiles. The need to communicate in a foreign language, caused by the demands of the labor market, necessitates the possession of social and communication skills.

First of all, it is necessary to interpret correctly the term "soft skills". The scientist O. Kazachiner gives the following definition: "Soft skills" is a kind of list of personal characteristics that are somehow related to effective interaction with other people. These are skills that are difficult to detect, directly identify, test, and demonstrate. This group includes individual, communication and management skills" (Kazachiner, 2019: 154). The term "soft skills" is often correlated with "hard skills" (professional knowledge, skills and abilities) which are easy to measure; they are quite objective (Koval, 2015: 163).
As a result of their studies, applicants for higher education - future law enforcement and military officers - must have the following general competencies: be able to work in an international context; have skills in the use of information and communication technologies; ability to communicate in a foreign language; interpersonal skills; ability to plan and manage time, have respect for diversity and multiculturalism. These competencies will maximally contribute to the formation of "soft skills" in the process of learning foreign languages and will allow graduates to be competitive not only in the domestic labor market but also abroad. According to the researcher Yu. Lavrysh, the most important for adaptation in the modern world are such properties as a high level of responsibility, as well as social activity and competence in interpersonal communication and professional interaction, creativity for successful adoption and application of non-standard decisions (Lavrysh, 2015: 105).

Teaching methods play an important role not only in the effective acquisition of knowledge, but also in the formation of social skills. One of the most important aspects of the formation of "soft skills" in the process of learning foreign languages is the communicative orientation. After all, such social skills as flexibility and adaptability, skills of teamwork and being a leader in it, require the ability to communicate effectively. The communicative approach is leading in the study of a foreign language.

Interactive teaching methods, i.e. a set of certain tools and technologies to intensify the learning process and establish interaction between students, are extremely popular and effective in learning a foreign language. When using interactive methods, the emphasis during the lesson is transferred from the teacher to the students and their interaction with each other and with the teacher. During interactive learning, communication skills and abilities, ability to work in a team, to cooperate are being developed. The use of interactive teaching methods are advanced means in the process of learning a foreign language, which are based primarily on a person-centered approach to the student, aimed at developing students' creativity, communication skills, ability to think and react quickly. As the researcher G. Hushcha notes, "according to the communicatively oriented approach to learning a foreign language, priority is given to such areas of work as writing works, essays; preparation of reports, projects, researches; preparation of a public speech / presentation, with the help of appropriate means of verbal communication and adequate forms of discussions and debates" (Hushcha, 2020: 30).

The Ukrainian scientists L. Pyrozhenko and O. Pometun classify interactive technologies by 
forms of learning and provide four groups depending on the purpose of the class and forms of organizing of students' activities: interactive technologies of cooperative learning, interactive technologies of group learning, situational modeling technologies, and technologies of discussion issues (Pometun, Pirozhenko, 2004). Therefore, we will consider the development of "soft skills" in the process of learning a foreign language using certain methods from the above 4 groups of interactive learning technologies, which are actively used by us in the educational process in training future police and military officers and are, in our opinion, most effective and efficient.

The first group is interactive technologies of cooperative learning. The essence of cooperative learning is to receive instruction from the teacher and group into small teams or pairs. Students and cadets complete the task until all members of the group complete it successfully. An important element of cooperative learning is the processing and discussion of the results of groups or pairs. That is, there is an analysis of the cooperation of group members or couples and the ways to improve efficiency are identified. Thus, in the process of cooperative learning, leadership skills, decision-making, trust building, communication and conflict resolution are developed. Among the methods of this group, we highlight the following: - "Dialogue" - a joint search by groups for an agreed solution that includes confrontation and criticism of the positions of other groups; - "Circle of ideas" - the solution of sharp contradictory ideas with the involvement of all students to discuss the issue. All groups must perform the same task, which consists of several questions (positions), which groups represent in turn; - "Joint project" is also similar to dialogue in that it has the same goal and grouping, but the tasks given to the groups have different content and cover the problem from different points of view.

The second group is interactive technologies of collective-group learning, which includes interactive technologies that involve the simultaneous joint work of the whole group:

- "Microphone" - a kind of general group discussion, in which the teacher asks students to quickly express their opinion on a particular issue in an imaginary improvised microphone, which is transmitted from student to student as each expresses his opinion;

- "Brainstorming" is an interactive technology of collective discussion, which aims to gather as many ideas about the problem from all students for a limited period of time. The idea is that one group of students (generators of ideas) express as many ideas as possible, and another group (experts) give them an assessment, select the most valuable thoughts and ideas. Brainstorming encourages students to show imagination and creativity, gives them the opportunity to freely express their thoughts;

- "Teaching-learning" is used in the study of the block of information or in the generalization and repetition of the studied. It gives students the opportunity to participate in the transfer of their knowledge to groupmates. The essence of this method is that the teacher prepares cards with facts related to the topic of the class, one for each student and distributes one card to each student. For a few minutes they read the information on the card. Then they are invited to move around the audience and share their information with other groupmates. A student can only talk to one person at a time. The task is to share your fact and get information from another student. In the allotted time, it is necessary to ensure communication of each student with the maximum number of others to obtain as much information as possible. After students complete this exercise, they should be asked to tell, reproduce the information obtained. Answers can be written on the board.

The third group is situational modeling technologies (i.e. situational games). In our opinion, the most productive here are simulation and stimulation games, which develop imagination and critical thinking skills, promote the practical application of problem-solving skills, and stimulation allows students to get deep into the problem, to understand it from the inside. In addition, role-playing is also effective because it allows students and cadets to practice communicating in different social contexts and different social roles. Role-playing games simulate real life situations and allow participants to act as in a real situation.

The fourth group is discussion technologies. Discussion promotes the development of critical thinking, gives the opportunity to determine their own position, develops skills to defend their own opinion and deepens knowledge of the issue under discussion. Among the methods of this group are popular method "take the position", the method "change the position", debates and others.

Conclusions. In the process of learning foreign languages, active learning technologies are widely used, which are based on building an active learning environment, on problem-situational learning practices, developing cases and mini-games, organizing educational competitions, on independent scientific creativity, but not just on reproduction of already available information that will contribute to the formation of "soft skills". Characteristic features of these teaching methods are personality-oriented and student-centered approaches to the educational process, 
because one of the main tasks in the process of teaching foreign languages is the development of independent problem thinking in higher education, as well as skills to manipulate information, not just language orientation. Achieving this goal will contribute to the focus on subject-subject, dialogic interaction between teacher and students, which naturally leads to the need to implement the educational process through both traditional and innovative teaching methods in their harmonious combination.

\section{BIBLIOGRAPHY}

1. Гуща Г. Місце і роль іноземної мови в формуванні soft skills. "Soft skills" - невід'ємні аспекти формування конкурентоспроможності студентів у XXI cm. Київ : Київ. нац. торг-екон. ун-т, 2020. С. $28-31$. URL: https://knute.edu.ua/file/NjY4NQ==/f5e21f8fa4b196951d084e7e586ab122.pdf (дата звернення: 11.05.2021).

2. Казачінер O. "Hard skills" та "soft skills" інклюзивно компетентного вчителя іноземної мови. Інноваційна педагогіка. 2019. Т. 1. С. 153-156. URL: http://www.innovpedagogy.od.ua/archives/2019/10/part_1/35.pdf (дата звернення: 11.05.2021).

3. Коваль К. Розвиток "soft skills" у студентів - один із чинників для їх працевлаштування. Вісник Вінницького політехнічного інституту. 2015. № 2. C. 162-167. URL: https://visnyk.vntu.edu.ua/index.php/visnyk/article/view/827/826 (дата звернення: 12.05.2021).

4. Лавриш Ю. Навички соціальної взаємодії як необхідна складова підготовки інженерів у сучасному університеті Гуманітарний вісник Державного вищзго навчального закладу «Переяслав-Хмельницький державний педагогічний університет імені Григорія Сковороди». 2015. Вип. 37. С. 104-111. URL: http://nbuv.gov.ua/UJRN/ gvpdpups_2015_37_14 (дата звернення: 12.05.2021).

5. Основні засади мовної підготовки особового складу в системі Міністерства оборони України : вих. документ Міністерства оборони України № 1524/3/84 від 08.08.2019 р. 2019. 34 с.

6. Пометун О., Пироженко Л. Сучасний урок. Інтерактивні технології навчання. Київ, 2004. 192 с.

7. Boone, J. Companies will struggle to fill posts, says survey. Financial Times of 25.02.2009.

8. Watts M., Watts R. K. Developing Soft Skills in Students. 2008. URL: http://108.cgpublisher.com/proposals/64/index html (Accessed on: 10.05.2021).

\section{REFERENCES}

1. Hushcha H.V. Mistse i rol' inozemnoyi movy v formuvanni soft skills [The place and role of a foreign language in the formation of soft skills]. "Soft skills" - nevid'yemni aspekty formuvannya konkurentospromozhnosti studentiv u XXI stolitti. Kyyiv: Kyyiv. nats. torh.-ekon. un-t, 2020. - S. 28-31. URL: https://knute.edu.ua/file/NjY4NQ==/ f5e21f8fa4b196951d084 e7e586ab122.pdf (data zvernennya: 11.05.2021).

2. Kazachiner O.S. "Hard skills" ta "soft skills" inklyuzyvno kompetentnoho vchytelya inozemnoyi movy ["Hard skills" and "soft skills" of an inclusively competent foreign language teacher]. Innovatsiyna pedahohika. 2019. T. 1. S. $153-156$. URL: http://www.innovpedagogy.od.ua/archives/2019/10/part_1/35.pdf (data zvernennya: 11.05.2021) [in Ukrainian]

3. Koval' K.O. Rozvytok "soft skills" u studentiv - odyn z chynnykiv dlya yikh pratsevlashtuvannya [The development of "soft skills" in students is one of the factors for their employment]. Visnyk Vinnyts'koho politekhnichnoho instytutu. 2015. № 2. S. 162-167. URL: https://visnyk.vntu.edu.ua/index.php/visnyk/article/view/827/826 (data zvernennya: 12.05.2021) [in Ukrainian].

4. Lavrysh Yu. Navychky sotsial'noyi vzayemodiyi yak neobkhidna skladova pidhotovky inzheneriv u suchasnomu universyteti [Social interaction skills as a necessary component of training engineers in a modern university]. Humanitarnyy visnyk Derzhavnoho vyshchoho navchal'noho zakladu "Pereyaslav-Khmel'nyts'kyy derzhavnyy pedahohichnyy universytet imeni Hryhoriya Skovorody”. 2015. Vyp. 37. S. 104-111 URL: http://nbuv.gov.ua/UJRN/gvpdpups_2015_37_14 (data zvernennya: 12.05.2021) [in Ukrainian].

5. Osnovni zasady movnoi pidgotovky osobovogo skladu v systemi Ministerstva oborony Ukrainy [The basic principles of language training of personnel in the system of the Ministry of Defense of Ukraine]. Vykhidnyi document Ministerstva oborony Ukrainy, 154/z/84, 8 serpnia 2019 r. [in Ukrainian]

6. Pometun, O. \& Pyrozhenko, L. (2004). Suchasnyi urok. Interaktyvni tekhnolohii navchannia [Modern lesson. Interactive technologies of study]. Kyiv [in Ukrainian].

7. Boone, J. Companies will struggle to fill posts, says survey [Текст] / Jon Boone. - Financial Times of 25.02.2009.

8. Watts, M. Developing Soft Skills in Students [Текст] / M. Watts, R. K. Watts // 2008. Available at: http://108.cgpublisher.com/proposals/64/index_html (Accessed on: 10.05.2021). 